according to Indian custom, to his profession. He was sagacions, cunning, and had a perfect knowledge of Indian character; prerequisites which were essential to sustain his character as a prophet among his people; and he had much to do in directing the career of Black Hawk and his band in their difficulties with the whites. White Cloud advised Black Hawk not to leave his village, but to remain there peaceably, and endeavor to persuade Keokuk and his band to return to Rock River, and probably the whites would leave. He now joined the hunting party, and hunted till spring. When they returned from their hunt, they found the whites still at their village, engaged in fencing up their corn-fields and preparing to cultivate them. Soon after they returned in the spring Keokuk paid them a visit at Rock River. He informed Black Hawk, that he had been to St. Louis, that he had accomplished nothing with the Agent there; and instead of giving his assent to return to their old village, as White Cloud had advised, he used all his influence to persuade the remainder of the Indians to follow him, and establish their lorlges on the Iowa where he resided. This he urged as a matter of policy to preserve peace, and not embroil the nation in difficulties with the whites. Black Hawk taunted Keokuk with cowardice, for thus wishing to quietly give up their village and the graves of their fathers to strangers, who had no right to the soil; and this interview only widened the breach of friendship which existed between them.

(To be continued.)

\title{
RECOLLECTIONS OF THE EARLY SETTLEMENT OF LEE COUNTY, IOWA.
}

"To the Editor of the 'ANNals of IOWA:'

"I received, some time ago, from Col. James C. Parrott, now postmaster at Keokuh, a very interesting letter, of which the following is a copy. It was not intended for publication; but I found that I could not well condense or abbreviate it. I therefore send it for publication entire in the 'Annals.'

"Yours respectfully,
"Fort Madison, Iowa, June 1, 1868.",

EDWARD JOHNSTONE.

How. Edward Johnstone, Dear Sir : At your request I proceed to give you the following memoranda, incidents, \&c., of the early settlement of Lee county, Iowa: 
I came to the county in September, 1834, a member of Company "I," 1st U. S. Dragoons, and was garrisoned at Camp Des Moines-now known as Montrose. This post was commanded by Lt. Col. Stephen W. Kearney, and the command consisted of companies " B," " $\mathrm{H}$," and " $\mathrm{I}$," commanded respectively by Captains E. V. Surnner, Nathaniel Boone, and I. B. Brown, On our arrival the quarters for the troops were being erected by Lieut. Crossman, U. S. QuarterMaster, and were finished for occupancy about the 1st of October.

The only improvement on our arrival was a $\log$ house and a small field of corn ; Capt. Jas. W. White being the occupant. The Government purchased his claim, and the house was used as a hospital to the post.

There were many traces of a former settlement around the camp, the most prominent of which was the old orchard of apple-trees a short distance below. The orchard at that time contained some ten or tifteen trees in bearing condition. The fruit was very ordinary, being a common seedling. The Indians were in the habit of visiting the orchard, and gathering the fruit in its green state, so that none of it, to my knowledge, ever came to perfection. There were also some sage bushes growing in the prairie to the rear of the camp; and there were, also, remains of dirt, or adobe, chimneys visible in the same locality; which goes to prove that a settlement had existed there at some former period.

There were numerous mounds in the vicinity of the camp, and there were many speculations and conjectures as to their origin. Some believed them to have been the fortifications of the Spaniards, while others thought they were the burial places of the Indians. The latter, I think, is correct; as I witnessed an Indian burial in one of them.

The troops remained at Camp Des Moines until the spring of 1837 , when they were remored to Fort Leavenworth.

There were but f'ew settlements, on the arrival of the troops; on the road or trail leading from the camp to the foot of the rapids. There were a few cabins at Nashville, and, in a short 
time after, a house was built by Stephen H. Burtis about one and a half mile below the camp; also, a little further down, a cabin was built and occupied by Ezra Overall. This was all between the camp and the foot of the rapids, where there was an old trading house, known in after years as "Rat Row," and two or three other cabins. This was then called "The Point;" now, Keoknk-named in honor of Keokuk, the chief of the Sac tribe of Indians.

There were a few citizens at this place in 1834 ; a few or most of whom I will name: Campbell, John Gaines, Bill Price, Alexander Hood, Bill McBride, Thos. W. Taylor, Val. "Wanorsdall, and a few others, some of whom, to use a common phrase, were "hard cases," but, notwithstanding, they were useful citizens. They engaged in the lighting and towing business over the rapids, which at that day was indispensable, as it was impossible to get goods or merchandise over them in steamboats.

The old building known as "Rat Row" had its many uses, as is usual in all frontier towns. It was at once a hotel, church, court house, and grocery; the latter named being, at that time, the most popular of them all.

From the camp to Fort Madison there was but one cabin in 1834, which was situated near what is known as Webster's Big Spring, and was occupied by a man named Foster. Fort Madison contained a few cabins; and, if my memory serves me correctly, Small, Cheney, and IIorton, were among the early settlers. John and Nathaniel Knapp made their purchase of them, I think, in 1835, and laid out the town, the western boundary of which was near where the McFarland 2 House now stands. From there down, or what was called in early times the lower town, was laid out by Joseph Webster."

There were at this early day many traces of the old Fort visible. Some of the stockades, the locality of the block houses, and marks of the subterranean cavern through which the troops made their escape, were plainly to be seen. Also, the old garrison well, which at that time supplied the inhabitants of the town with water, and, I think, supplies some of them to this day. 
William Skinner was employed by the Quarter-Master in erecting the buildings at Camp Des Moines in 1834; and the same fall he made a claim or improvement on Devil Creek, which is now known as Applegate's. This, I think, is one of the first claims made in Lee county, off the Mississippi River. In the spring of 1835 , there were several claims made. Among the settlers was Howard, who made a claim on Sugar Creek, which locality is now known as Howard's Settlement. Thos. Clark made a claim which was known as Clark's Point; and 'Cruikshank, known as Cruikshank's Point. There were also made, in the same year, several claims where South Augusta now stands. The noted Spurlock was one of those settlers, and E. D. Ayres, John Bơx, Thos. Wilšon, and Hugh Dunn, made claims near Fort Madison.

In 1834, our Territory was attached to Michigan for judicial purposes, and contained but two counties, viz: Des Moines and Dubuque. The boundary line was the Iowa River; and Burlington, then known as "Flint Hills," was the county town of Des Moines county.

In the fall of 1836, John and Nathaniel Knapp erected two large frame houses, known as the "Madison" and "Washington" houses. These were the first improvements of any note made in Fort Madison.

In the years 1836 and 1837 , there was quite an influx of population into Fort Madison, and town lots brought high prices. There are some of those old settlers still living, but many of them have long since paid the debt of nature. Among the living are Peter Miller, Philip Viele, Daniel 'McCoun, Harmon 'Dingman, and others.

I think in 1835 or 1836 , the Territory was organized into counties, and the county of Lee was named for Lieut. Robert E. Lee (now General Lee), who was at that time making the Government survey of the Des Moines, or lower Rapids. Our first Territorial Legislature was held at Dodgeville, Wis. At that time, we were attached to Wisconsin for judicial purposes. John Box was a representative from Lee county.

Judge Irvin, I think, held the first District Court in Lee 
county, and John II. Lines was the first District Clerk. The Court was held in the "Madison House."

Lee county, at an early day, abounded with large quantities of game - deer, turkeys, \&c., being abundant. There were, also, large numbers of wolves; and it was noted, further, for its great quanity of wild honey. The water courses were much larger than at the present time. I have known Devil Creek to be impassable for two weeks at a time from high water, and there was a saw mill on that stream a short distance above where the bridge now crosses it on the road from Montrose to Fort Madison, which run from six to seven months in the year. Skunk River was also considered navigable, although it was dammed at Augusta, and a grist and saw mill was established there in 1835 . I think John Whitaker was interested in the mills.

I was informed by Frank Labiseur, United States Interpreter for the Sac and Fox Indians, that the name of Skunk River was a wrong interpretation. The Indian name was Chicaque, which, in their laugnage, is anything of a strong or obnoxious smell-such as onion, skunk, \&c. From the fact that the head-waters of said stream abound with wild onions, the interpretation should have been "onion."

The Sac and Fox tribes were in quite large numbers in this connty in 1834 . Black Hawk and his family made, for several years, the bottom lands of Devil Creek their winter quarters. In the spring they would manufacture quite a quantity of maple sugar, from the numerons sugar trees then in that locality.

Keokuk was the chief of the Sac Indians. He was a man of fine personal appearance, but was of profligate habits, being much addicted to intemperance. Appanoose, the chief of the Fox Indians, was a sedate, quiet man, and was much beloved by his tribe. His principal village was where Iowaville now stands.

The foregoing statements are made entirely from memory, having no notes to which to refer; but I think, as far as they go, they are correct; and I hope they may be of some service to you in perpetuating the early history of Lee county.

Very respectfully, your obedient servant, KEOKUK, IowA.

J. C. Parrott. 
Copyright of Annals of Iowa is the property of State of Iowa, by \& through the State Historical Society of Iowa and its content may not be copied or emailed to multiple sites or posted to a listserv without the copyright holder's express written permission. However, users may print, download, or email articles for individual use. 